\title{
PENGARUH INTERVENSI MEDIA SOSIAL (WHATSAPP) DENGAN FLYER TERHADAP PERUBAHAN PERILAKU MEROKOK REMAJA PADA MASA PANDEMI COVID-19 DI DESA TOMADO KECAMATAN LINDU
}

\author{
Yusuf $^{1}$, Muhammad Syafar ${ }^{2}$, Nur Indriani Agus ${ }^{3}$ \\ Program Studi Pascasarjana Kesehatan Masyarakat \\ Sekolah Tinggi Ilmu Kesehatan Tamalatea Makassar \\ yusuf@stiktamalateamks.ac.id ${ }^{1}$, syafar.muhammad@yahoo.co.id ${ }^{2}$
}

\begin{abstract}
Adolescent smoking behavior is a behavior that endangers health, but there are still many teenagers who become smokers who started when they were teenagers or at the age of 11 years, especially teenage boys who often did this action. The use of appropriate media can affect the knowledge of respondents. In general, this study aims to determine the effect of social media intervention (whatsapp) with flyers on changes in adolescent smoking behavior during the COVID-19 pandemic in Tomado Village, Lindu District, Sigi Regency, Central Sulawesi. And specifically, the research objective was to determine the effect of social media intervention (whatsapp) with flyers on smoking knowledge, smoking frequency, changes in smoking attitudes, and adolescent motivation to quit smoking. This type of research is a quasi-experimental design with a pretest-posttest two group design. The research sample used purposive sampling method and obtained a sample of 40 people. The instrument of this research used questionnaires, observation sheets, pretest and posttest questionnaires, and media flyers. Analysis of research data using a comparative test, namely Paired sample t-test, and Independent t-test. The results showed that there was a significant difference in respondents' knowledge about the dangers of smoking in the intervention group, while in the control group it was found that there was no significant difference in respondents' knowledge;
\end{abstract}

Kata kunci: $\quad$ Flyer, Social Media Intervention, Smoking Behavior, Youth.

\begin{abstract}
ABSTRAK
Perilaku merokok remaja adalah perilaku yang membahayakan kesehatan, tetapi masih banyak remaja yang menjadi perokok yang dimulai ketika masih remaja atau usia 11 tahun, khususnya remaja lakilaki yang sering melakukan tindakan ini. Penggunaan media yang tepat dapat mempengaruhi pengetahuan responden. Secara umum penelitian ini bertujuan untuk mengetahui pengaruh intervensi media sosial (whatsapp) dengan flyer terhadap perubahan perilaku merokok remaja pada masa pandemi covid-19 di Desa Tomado Kecamatan Lindu Kabupaten Sigi, Sulawesi Tengah. Dan secara khusus tujuan penelitian yaitu untuk mengetahui pengaruh intervensi media sosial (whatsapp) dengan flyer terhadap pengetahuan merokok, frekuensi merokok, perubahan sikap merokok, dan motivasi remaja untuk berhenti merokok. Jenis penelitian ini adalah quasi exsperimen dengan rancangan pretest-posttest two group design. Sampel penelitian menggunakan metode purposive sampling dan diperoleh sampel sebanyak 40 orang. Instrumen penelitian ini menggunakan kuisioner, lembar observasi, kuisioner pretest dan posttest, serta media flyer. Analisis data penelitian menggunakan uji komparatif, yaitu Paired sample t-test, dan Independent t-test. Hasil penelitian dapat diketahui adanya perbedaan yang signifikan pengetahuan responden tentang bahaya rokok pada kelompok intervensi, sedangkan pada kelompok kontrol ditemukan bahwa tidak ada perbedaan yang signifikan pada pengetahuan responden; adanya perbedaan yang signifikan frekuensi merokok remaja pada kelompok intervensi dan kelompok kontrol; adanya perbedaan yang siginifikan sikap merokok remaja pada kelompok intervensi maupun kelompok kontrol; adanya perbedaan yang siginifikan motivasi berhenti merokok pada kelompok intervensi maupun kelompok kontrol.
\end{abstract}

Kata kunci: $\quad$ Flyer, Intervensi Mediasosial, Perilaku Merokok, Remaja 


\section{PENDAHULUAN}

Perilaku merokok adalah suatu perilaku yang memiliki resiko terhadap kesehatan, tetapi masih banyak orang-orang yang menjadi perokok, bahkan seseorang memulai menjadi perokok sejak usia remaja. Data yang ditunjukkan oleh World Health Organization, WHO (2020) atau Badan Kesehatan Dunia, disebutkan bahwa 1 dari 10 kematian pada orang-orang yang sudah dewasa disebabkan oleh rokok, dan yang menyebabkan hampir 5 juta orang yang meninggal dunia setiap tahun. Jika keadaan ini terus berlanjut, pada tahun 2020, pada setiap tahunnya 10 juta orang akan meninggal, dan $70 \%$ kejadian-kejadian akan ada pada negara berkembang seperti halnya di negera Indonesia. Ditahun 2030 kemungkinan terburuk dengan perkiraan angka kematian akan sampai pada angka yang tinggi yakni dengan jumlah 8 juta jiwa kematian (Rochayati \& Hidayat, 2015).

Dibandingkan dengan data survei pada tahun 1995 yaitu (27\%), kebiasaan perokok di Indonesia cenderung terjadi peningkatan sebesar 34,7\% pada tahun 2010 (Kementerian Kesehatan RI, 2012). Berdasarkan laporan dari Kementrian Kesehatan RI (2010) data Riskesdas di Indonesia, data menunjukkan penduduk dengan usia $\geq 15$ tahun dengan presentasi $34,7 \%$ adalah perokok. Antara tahun 2001 hingga 2010, tingkat merokok semua kelompok umur 10-14 tahun sekitar 80\%, dan ditahun 2013, jumlah perokok di atas 15 tahun di Indonesia mencapai 36,3\%. Jika perbandingan dilakukan pada penelitian Global Adults Tabacco Survey (GATS) pada kelompok usia $\geq 15$ tahun, rasio dari perokok pria yaitu $67,0 \%$ lebih tinggi dari Riskesdas 2013 yang mencapai 64,9\% (Kusumawardani et al., 2016).

Hasil olah data Badan Pusat Statistik (BPS, 2020) untuk Provinsi Sulawesi Tengah persentase merokok pada penduduk umur lebih dari atau sama dengan 15 tahun adalah 35,57\% ditahun 2018, dan ditahun
2019 adalah 31,64\%, sedangkan ditahun 2020 yakni 30,64\%. Diantara ketiga presentase tersebut semuanya menunjukkan angka yang paling tinggi diantara provinsi lainnya yang ada di pulau Sulawesi. Berdasarkan penjelasan dari UNICEF Indonesia (2021) yang mengemukakan Di Sulawesi Tengah, dengan umur yang masih 17 tahun 80 persen remaja, orang dewasa, dan lansia di lingkungan tempat tinggal menjadi perokok aktif, hal itu terjadi karena dari pemasaran dan promosi produk rokok sebagai faktor utamanya.

Kajian oleh Gafar (2014) berjudul "Dampak Promosi Kesehatan Melalui Sosial Media Facebook Terhadap Pengetahuan Bahaya Merokok Pada Mahasiswa PSIK Semester 8 Universitas Muhammadiyah Yogyakarta" dengan hasil penelitian bahwa sebelum promosi kesehatan, 20 responden dengan pengetahuan sedang atau (53\%). Sesaat sesudah promosi kesehatan dilakukan meningkat menjadi 35 responden atau $(92,0 \%)$ dengan pengetahuan mahasiswa termasuk dalam kategori tinggi. Maka kesimpulannya bahwa peningkatan derajat kesehatan mahasiswa PSIK semester 8 Universitas Muhammadiyah Yogyakarta berdampak pada tingkat pengetahuan bahaya merokok.

Studi lain juga menunjukkan satu dari dua orang perokok yang telah menjadi perokok selama masa remaja dan yang merokok selamanya pada akhirnya akan mati karena penyakit yang disebabkan oleh rokok. Perokok yang secara terus menerus menjadi perokok untuk jangka waktu yang lama akan menemui kecenderungan kematian tiga kali lebih tinggi dibandingkan yang non-perokok (Nasution, 2007).

Pemerintah telah melakukan upaya untuk mengurangi perokok aktif, dan pemerintah lewat Peraturan Menteri Kesehatan Nomor 28 Tahun 2013, mengamanatkan bahwa kemasan produknya memuat gambar bahaya merokok. Peraturan ini mulai berlaku pada 24 Juni 2014 
(Republik Indonesia, 2013). Namun usaha tersebut belum secara signifikan menurunkan angka perokok khususnya remaja (Ramdhani et al., 2014).

Merokok berdampak negatif bagi tubuh, terutama para perokok ini mulai merokok ketika masih muda seperti halnya pemuda atau remaja di Kecamatan Lindu. Tidak hanya remaja yang sedang merokok yang dapat berdampak negatif bagi kesehatannnya, tetapi juga orang sekitar atau teman-teman yang menghirup asap rokoknya. Jika kondisi ini tidak tertangani lebih cepat, jumlah remaja perokok di kawasan tersebut akan terus meningkat setiap tahunnya dan bermunculan penyakit lainnya yang dapat menyerang para remajanya. Oleh karena itu upaya serius sangat perlu dilakukan untuk memangkas para perokok-perokok remaja di Desa Tomado Kecamatan Lindu Kabupaten Sigi.

Berbagai teknik dan metode dapat digunakan untuk berhenti merokok untuk peningkatan semangat dan tersadarnya para remaja yakni dengan penggunaan pendidikan kesehatan. Media yang dipergunakan seperti flyer, gambar, video, poster, dan lain-lain (Kusuma, 2019). Di Italia, adanya gambar peringatan sangat efektif untuk terjadinya peningkatan motivasi dan perilaku berhenti merokok remaja (Mannocci et al., 2014). Pendidikan kesehatan dapat disampaikan secara tidak langsung lewat media elektronik mulai dari komputer, telepon, dan gadget (Notoatmodjo, 2007). Hal ini sejalan dengan model praktik keperawatan Locsin yang menyatakan bahwa dengan menggunakan media komputer, telepon, dan gadget mampu membuat terjadinya peningkatan aktivitas keperawatan untuk memberikan perawatan kepada pasien yang kualitasnya bagus. Locsin juga menambahkan bahwa teknologi ada dalam keperawatan atau caring in nursing, dan ada keterkaitan yang harmonis diantara caring dalam keperawatan dengan teknologi (Locsin, 2007).
Whatsapp adalah media sosial yang banyak digunakan oleh masyarakat. Saat ini rata-rata masyarakat terutama yang bekerja dan anak sekolah menggunakan media sosial whatsapp untuk saling berbagi kabar dan informasi di situasi pandemic Covid-19.

\section{METODE}

Jenis penelitian yang digunakan dalam penelitian ini adalah quasi exsperimen dengan memberikan perlakuan kepada kelompok eksperimen dan terdapat kelompok kontrol sebagai pembanding.

Penelitian ini dilakukan di Desa Tomado Kecamatan Lindu Kabupaten Sigi Provinsi Sulawesi Tengah. Yang dilakukan pada bulan Februari 2021 sampai dengan bulan Juni 2021.

Adapun populasi dari penelitian ini yaitu semua remaja yang tinggal di Desa Tomado Kecamatan Lindu Kabupaten Sigi sebanyak 72 orang. Sampel penelitian ini adalah menggunakan metode purposive sampling. Dan diperoleh sampel sebanyak 40 orang. Sampel dipilih dengan kriteria dia adalah remaja laki-Laki, remaja dengan rentang usia 14-21 Tahun, dan merokok minimal 2 bulan.

Dengan rancangan penelitian yang digunakan adalah pre test dan post test two group. Dalam desain ini observasi dilakukan dua kali yaitu sebelum eksperimen dan sesudah eksperimen.

Desain ini terdiri atas dua kelompok yang masing-masing diberikan pretest dan posttest yang kemudian diberi perlakuan dengan metode intervensi melalui media sosial (whatsapp) dengan flyer dan tanpa menggunakan metode intervensi melalui media sosial (whatsapp) dengan flyer.

Instrumen penelitian ini menggunakan kuisioner, lembar observasi, kuisioner pretest dan posttest, serta media flyer. Analisis statistic menggunakan uji komparatif Paired sample ttest, dan Independent t-test. 


\section{HASIL}

\section{Analisis Univariat}

Pada penelitian ini dilakukan analisis univariat pada karakteristik umum responden maupun variabel penelitian yang bertujuan untuk mengetahui sebaran frekuensi responden berdasarkan karakteristik responden dan variable-variabel yang diteliti.

\section{Karakteristik Umum Responden}

Tabel 1. Distribusi Responden Berdasarkan Karakteristik Umum Responden pada Kelompok Intervensi dan Kelompok Kontrol

\begin{tabular}{lllll}
\hline $\begin{array}{l}\text { Karakteristik } \\
\text { Responden }\end{array}$ & \multicolumn{2}{c}{$\begin{array}{l}\text { Kelompok } \\
\text { Intervensi }\end{array}$} & \multicolumn{2}{c}{$\begin{array}{l}\text { Kelompok } \\
\text { Kontrol }\end{array}$} \\
\cline { 2 - 5 } & $\mathbf{n}$ & $\mathbf{\%}$ & $\mathbf{n}$ & $\mathbf{\%}$ \\
\hline Umur & & & & \\
14-15 Tahun & 2 & $10 \%$ & 1 & $5 \%$ \\
16-17 Tahun & 7 & $35 \%$ & 7 & $35 \%$ \\
18-19 Tahun & 6 & $30 \%$ & 5 & $25 \%$ \\
20-21 Tahun & 5 & $25 \%$ & 7 & $35 \%$ \\
\hline Lama Merokok & & & & \\
<1 Tahun & 2 & $10 \%$ & 2 & $10 \%$ \\
1-2 Tahun & 14 & $70 \%$ & 11 & $55 \%$ \\
3-4 Tahun & 3 & $15 \%$ & 6 & $30 \%$ \\
>4 Tahun & 1 & $5 \%$ & 1 & $5 \%$ \\
\hline Ayah Merokok & & & & \\
Ya & 18 & $90 \%$ & 18 & $90 \%$ \\
Tidak & 2 & $10 \%$ & 2 & $10 \%$ \\
\hline Total & $\mathbf{2 0}$ & $\mathbf{1 0 0 \%}$ & $\mathbf{2 0}$ & $\mathbf{1 0 0 \%}$ \\
\hline
\end{tabular}

(Sumber, Data primer 2021)

Tabel 1 menunjukkan bahwa jumlah responden untuk masing-masing kelompok intervensi dan kelompok kontrol adalah 20 orang.

Jumlah responden pada kelompok intervensi berdasarkan umur paling banyak adalah 16-17 tahun sebesar 35\% dan yang paling sedikit yaitu kelompok umur 14-15 tahun sebsar 10\% . Responden berdasarkan umur pada kelompok kontrol yang paling banyak adalah 16-17 tahun dan 20-21 tahun masing-masing sebesar $35 \%$ dan yang paling sedikit adalah kelompok umur 14-15 tahun sebesar 5\%. Karakteristik responden berdasarkan lama merokok pada kelompok intervensi dan kelompok kontrol. Pada kelompok intervensi responden dengan lama merokok tertinggi yaitu 1-2 tahun sebesar 70\% dan terendah $>4$ tahun sebesar 5\% sedangkan pada kelompok kontrol responden dengan lama merokok tertinggi yaitu 1-2 tahun sebesar 55\% dan terendah yaitu $>4$ tahun sebesar 5\%.

Karakteristik responden berdasarkan status ayah merokok pada kelompok intervensi dan kontrol sama yaitu masing-masing sebesar $90 \%$ untuk status ayah merokok dan $10 \%$ untuk status ayah tidak merokok.

\section{Gambaran Pengetahuan, Frekuensi Merokok, Sikap, dan Motivasi Berhenti Merokok}

\section{Pengetahuan}

Dalam penelitian ini pengetahuan dibagi menjadi dua kategori yaitu kategori cukup (jika memiliki skor penilaian 7-10) dan kategori kurang (jika memiliki skor 0-6).

\section{Tabel 2. Gambaran Pengetahuan Remaja Tentang Bahaya Merokok di Desa Tomado Kecamatan Lindu Kabupaten Sigi 2021}

\begin{tabular}{llllll}
\hline \multirow{2}{*}{ Kelompok } & Kategori & \multicolumn{2}{c}{ Pretest } & \multicolumn{2}{c}{ Posttest } \\
\cline { 3 - 6 } & & $\mathbf{N}$ & $\mathbf{\%}$ & $\mathbf{N}$ & $\mathbf{\%}$ \\
\hline \multirow{2}{*}{ Intervensi } & Cukup & 9 & 45 & 13 & 65 \\
\cline { 2 - 6 } & Kurang & 11 & 55 & 7 & 35 \\
\hline \multirow{2}{*}{ Kontrol } & Cukup & 13 & 65 & 12 & 60 \\
\cline { 2 - 6 } & Kurang & 7 & 35 & 8 & 40 \\
\hline Total & & $\mathbf{2 0}$ & $\mathbf{1 0 0}$ & $\mathbf{2 0}$ & $\mathbf{1 0 0}$ \\
\hline
\end{tabular}

(Sumber, Data primer 2021)

Tabel 2 menunjukkan jumlah responden yang mengalami peningkatan tingkat pengetahuan pada kelompok intervensi sebelum dan sesudah intervensi. Responden yang memiliki tingkat pengetahuan cukup sebelum intervensi sebanyak $45 \%$ sedangkan setelah dilakukan intervensi meningkat menjadi $65 \%$. Pada kelompok kontrol mengalami penurunan yaitu tingkat pengetahuan cukup $65 \%$ menjadi $60 \%$.

\section{Frekuensi}

Penelitian ini, membagi frekuensi merokok menjadi tiga kategori yaitu kategori ringan (jika rokok yang dikonsumsi 1-4 batang per hari), kategori sedang (jika rokok yang dikonsumsi 514 batang per hari) dan kategori berat (jika rokok yang dikonsumsi $>15$ batang per hari). 
Tabel 3. Gambaran Frekuensi Merokok Remaja di Desa Tomado Kecamatan Lindu Kabupaten Sigi Tahun 2021

\begin{tabular}{llllll}
\hline Kelompok & \multirow{2}{*}{ Kategori } & \multicolumn{2}{c}{ Pre Test } & \multicolumn{2}{c}{ Post Test } \\
\cline { 3 - 6 } & & $\mathbf{N}$ & $\mathbf{\%}$ & $\mathbf{n}$ & $\mathbf{\%}$ \\
\hline \multirow{3}{*}{ Intervensi } & Ringan & 5 & 25 & 8 & 40 \\
\cline { 2 - 6 } & Sedang & 14 & 70 & 12 & 60 \\
\cline { 2 - 6 } Kerat & 1 & 5 & 0 & 0 \\
\hline \multirow{3}{*}{ Kontrol } & Ringan & 14 & 70 & 14 & 70 \\
\cline { 2 - 6 } & Sedang & 5 & 25 & 6 & 30 \\
\cline { 2 - 6 } & Berat & 1 & 5 & 0 & 0 \\
\hline Total & & $\mathbf{2 0}$ & $\mathbf{1 0 0}$ & $\mathbf{2 0}$ & $\mathbf{1 0 0}$ \\
\hline
\end{tabular}

(Sumber, Data primer 2021)

Tabel 3 menunjukkan bahwa frekuensi merokok remaja kelompok intervensi, sebelum dilakukan intervensi frekuensi merokok kategori sedang sebanyak $70 \%$ dan menurun menjadi $60 \%$ setelah dilakukan intervensi sedangkan frekuensi merokok kategori berat sebanyak 5\% dan menurun menjadi $0 \%$ setelah dilakukan intervensi.

Pada kelompok kontrol, frekuensi dengan kategori berat menurun dari 5\% menjadi $0 \%$ dan frekuensi kategori ringan tidak mengalami perubahan.

\section{Sikap}

Penelitian ini membagi kategori sikap remaja terhadap rokok menjadi tiga kategori yaitu kategori baik (jika memiliki skor penilaian >40), kategori cukup (jika memiliki skor penilaian 25-40) dan kategori kurang (jika memiliki skor penilaian $<25$ ).

\section{Tabel 4. Gambaran Sikap Merokok Remaja di Desa Tomado Kecamatan Lindu Kabupaten Sigi Tahun 2021}

\begin{tabular}{llllll}
\hline Kelompok & \multirow{2}{*}{ Kategori } & \multicolumn{2}{c}{ Pre Test } & \multicolumn{2}{c}{ Post Test } \\
\cline { 3 - 6 } & & $\mathbf{n}$ & $\mathbf{\%}$ & $\mathbf{n}$ & $\mathbf{\%}$ \\
\hline \multirow{3}{*}{ Intervensi } & Baik & 3 & 15 & 10 & 50 \\
\cline { 2 - 6 } & Cukup & 17 & 85 & 10 & 50 \\
\cline { 2 - 6 } & Kurang & 0 & 0 & 0 & 0 \\
\hline \multirow{3}{*}{ Kontrol } & Baik & 4 & 20 & 5 & 25 \\
\cline { 2 - 6 } & Cukup & 15 & 75 & 15 & 75 \\
\cline { 2 - 6 } & Kurang & 1 & 5 & 20 & 0 \\
\hline Total & & $\mathbf{2 0}$ & $\mathbf{1 0 0}$ & $\mathbf{2 0}$ & $\mathbf{1 0 0}$ \\
\hline
\end{tabular}

(Sumber, Data primer 2021)

Tabel 4 menunjukkan jumlah responden berdasarkan sikap merokok pada kelompok intervensi mengalami peningkatan yaitu kategori baik sebesar 15 sebelum intervensi dan meningkat menjadi 50 setelah intervensi.
Responden pada kelompok kontrol juga mengalami peningkatan yaitu kategori baik sebesar 20 meningkat menjadi 25 .

\section{Motivasi Berhenti Merokok}

Penelitian ini membagi kategori motivasi berhenti merokok pada remaja menjadi tiga kategori yaitu kategori tinggi (jika memiliki skor penilaian >22), kategori sedang (jika memiliki skor penilaian 16-22) dan kategori rendah (jika memiliki skor penilaian $<16$ ).

Tabel 5. Gambaran Motivasi Berhenti Merokok Remaja di Desa Tomado Kecamatan Lindu Kabupaten Sigi Tahun 2021

\begin{tabular}{llllll}
\hline Kelompok & Kategori & \multicolumn{2}{c}{ Pre Test } & \multicolumn{2}{l}{ Post Test } \\
\cline { 3 - 6 } & & $\mathbf{n}$ & $\mathbf{\%}$ & $\mathbf{n}$ & $\mathbf{\%}$ \\
\hline \multirow{3}{*}{ Intervensi } & Tinggi & 11 & 55 & 17 & 85 \\
\cline { 2 - 6 } & Sedang & 9 & 45 & 3 & 15 \\
\cline { 2 - 6 } & Rendah & 0 & 0 & 0 & 0 \\
\hline \multirow{3}{*}{ Kontrol } & Tinggi & 10 & 50 & 12 & 60 \\
\cline { 2 - 6 } & Sedang & 9 & 45 & 7 & 35 \\
\cline { 2 - 6 } & Rendah & 1 & 5 & 1 & 5 \\
\hline Total & & $\mathbf{2 0}$ & $\mathbf{1 0 0}$ & $\mathbf{2 0}$ & $\mathbf{1 0 0}$ \\
\hline
\end{tabular}

(Sumber, Data primer 2021)

Tabel 5 menunjukkan jumlah responden berdasarkan motivasi berhenti merokok pada kelompok intervensi mengalami peningkatan yaitu kategori motivasi tinggi sebesar 55 sebelum intervensi dan setelah dilakukan intervensi meningkat menjadi 85. Pada kelompok kontrol juga mengalami peningkatan, kategori motivasi tinggi sebesar 50 menjadi 60 .

\section{Analisis Bivariat}

Pada tahap ini dilakukan analisis bivariat antara variabel dependen dengan variabel independent. Analisis anatara variabel independent dan variabel dependen untuk mengetahui apakah ada pengaruh variabel independent terhadap variabel dependen pada kelompok intervensi dan kelompok kontrol.

\section{Pengetahuan}

Tabel 6 menunjukkan bahwa berdasarkan hasil uji paired t-test, pengetahuan pada remaja mengenai bahaya rokok pada kelompok intervensi ditemukan hasil bahwa ada perbedaan signifikan antara pengetahuan sebelum dan sesudah intervensi dimana nilai mean sebelum 
intervensi 6.50 dan setelah intervensi menjadi 7.05 dengan nilai $p$-value $=0.012(\mathrm{p}<0.05)$. Pada kelompok kontrol berdasarkan hasil uji paired t-test ditemukan bahwa tidak ada perbedaan siginifikan pengetahuan remaja tentang rokok dengan nilai rata-rata 7.05 menjadi 7.15 dengan nilai $p$-value $=0.577$ $(\mathrm{p}>0.05)$.

Tabel 6. Perbedaan Pengetahuan pada Kelompok Intervensi dan kelompok Kontrol Sebelum dan Sesudah Intervensi di Desa Tomado Kecamatan Lindu Kabupaten Sigi Tahun 2021

\begin{tabular}{llll}
\hline Kelompok & $\begin{array}{l}\text { Pre Test } \\
\text { Mean } \pm \text { SD }\end{array}$ & $\begin{array}{l}\text { Post Test } \\
\text { Mean } \pm \text { SD }\end{array}$ & $\begin{array}{l}\boldsymbol{P} \\
\text { Value }\end{array}$ \\
\hline Intervensi & $6.50 \pm 1.53$ & $7.05 \pm 1.35$ & $0.012^{*}$ \\
Kontrol & $7.05 \pm 1.19$ & $7.15 \pm 1.18$ & $0.577^{*}$ \\
\hline $\boldsymbol{P}$ Value & $0.214^{* *}$ & $0.815^{* *}$ & \\
\hline Sumber, Data Primer 2021 & & \\
*Paired T-Test & & \\
** Independen T-Test & &
\end{tabular}

Berdasarkan uji independent t-test ditemukan hasil bahwa sebelum dan sesudah perlakuan tidak ada perbedaan pengetahuan yang signifikan pada kelompok intervensi dan kelompok kontrol dengan nilai $p$-value $=0.214$ dan 0.805 ( $p>0.05)$.

\section{Frekuensi Merokok}

Tabel 7. Perbedaan Frekuensi Meokok pada Kelompok Intervensi dan kelompok Kontrol Sebelum dan Sesudah Intervensi di Desa Tomado Kecamatan Lindu Kabupaten Sigi Tahun 2021

\begin{tabular}{llll}
\hline Kelompok & $\begin{array}{l}\text { Pre Test } \\
\text { Mean } \pm \text { SD }\end{array}$ & $\begin{array}{l}\text { Post Test } \\
\text { Mean } \pm \text { SD }\end{array}$ & $\begin{array}{l}\boldsymbol{P} \\
\text { Value }\end{array}$ \\
\hline Intervensi & $8.0 \pm 3.78$ & $7.35 \pm 3.55$ & $0.027^{*}$ \\
Kontrol & $4.55 \pm 2.96$ & $4.35 \pm 2.81$ & $0.046^{*}$ \\
\hline $\boldsymbol{P}$ Value & $0.001^{* *}$ & $0.005^{* *}$ & \\
\hline $\begin{array}{l}\text { Sumber, Data Primer } 2021 \\
\text { *Wilcoxon }\end{array}$ & & \\
$* *$ Mann-whitney Test & &
\end{tabular}

Tabel 7 menunjukkan bahwa berdasarkan hasil uji wilcoxson, frekuensi merokok remaja pada kelompok intervensi ditemukan hasil bahwa ada perbedaan signifikan sebelum dan sesudah intervensi dengan nilai mean 8.0 menurun menjadi 7.35 dengan nilai $p$-value $=$ 0.027 ( $\mathrm{p}<0.05)$, sedangkan pada kelompok kontrol juga ditemukan hasil bahwa ada perbedaan signifikan dengan nilai mean 4.55 menurun menjadi 4.25 dengan nilai $p$-value $=$ $0.046(\mathrm{p}<0.05)$.

Berdasarkan uji mann-whitney test ditemukan hasil bahwa sebelum dan sesudah perlakuan terdapat perbedaan yang signifikan frekuensi merokok pada kelompok intervensi dan kelompok kontrol dengan nilai $p$-value $=$ 0.001 dan $0.005(\mathrm{p}<0.05)$.

\section{Sikap}

Tabel 8. Perbedaan Sikap pada Kelompok Intervensi dan kelompok Kontrol Sebelum dan Sesudah Intervensi di Desa Tomado Kecamatan Lindu Kabupaten Sigi Tahun 2021

\begin{tabular}{|c|c|c|c|c|c|}
\hline Kelompok & $\begin{array}{l}\text { Pre Test } \\
\text { Mean } \pm \text { SD }\end{array}$ & & $\begin{array}{l}\text { Post Test } \\
\text { Mean } \pm \text { SD }\end{array}$ & & $\begin{array}{l}P \\
\text { Value }\end{array}$ \\
\hline Intervensi & 38.40 & \pm & 39.60 & \pm & $0.002 *$ \\
\hline Kontrol & $\begin{array}{l}33.85 \\
5.04\end{array}$ & \pm & $\begin{array}{l}34.70 \\
4.79\end{array}$ & \pm & $0.003 *$ \\
\hline$P$ Value & $0.003 * *$ & & $0.001 * *$ & & \\
\hline
\end{tabular}

Tabel 8 menunjukkan bahwa berdasarkan hasil uji paired t-test, sikap merokok remaja pada kelompok intervensi ditemukan hasil bahwa ada perbedaan signifikan antara sikap sebelum dan sesudah intervensi dimana nilai mean sebelum intervensi 38.40 dan setelah intervensi menjadi 39.60 dengan nilai $p$-value $=$ $0.002(\mathrm{p}<0.05)$. Sedangkan pada kelompok kontrol berdasarkan hasil uji paired t-test ditemukan bahwa ada perbedaan siginifikan sikap merokok remaja dengan nilai rata-rata 33.85 menjadi 34.70 dengan nilai $p$-value $=$ $0.003(\mathrm{p}<0.05)$.

Berdasarkan uji independent t-test ditemukan hasil bahwa sebelum dan sesudah perlakuan terdapat perbedaan yang signifikan sikap merokok pada kelompok intervensi dan kelompok kontrol dengan nilai $p$-value $=0.003$ dan $0.001(\mathrm{p}<0.05)$.

\section{Motivasi Berhenti Merokok}

Tabel 9 menunjukkan bahwa berdasarkan hasil uji paired t-test, pada kelompok intervensi 
ditemukan hasil bahwa ada perbedaan signifikan motivasi berhenti merokok remaja sebelum dan sesudah intervensi dimana nilai mean sebelum intervensi 23.75 meningkat menjadi 25.25 dengan nilai $p$-value $=0.000$ $(\mathrm{p}<0.05)$. Sedangkan pada kelompok kontrol berdasarkan hasil uji paired t-test juga ditemukan bahwa ada perbedaan siginifikan dengan nilai rata-rata 23.30 menjadi 24.80 dengan nilai $p$-value $=0.001(\mathrm{p}<0.05)$.

Tabel 9. Perbedaan Motivasi Berhenti Merokok pada Kelompok Intervensi dan kelompok Kontrol Sebelum dan Sesudah Intervensi di Desa Tomado Kecamatan Lindu Kabupaten Sigi Tahun 2021

\begin{tabular}{|c|c|c|c|c|c|}
\hline Kelompok & $\begin{array}{l}\text { Pre Test } \\
\text { Mean } \pm \text { SD }\end{array}$ & & $\begin{array}{l}\text { Post Test } \\
\text { Mean } \pm \text { SD }\end{array}$ & & $\begin{array}{l}P \\
\text { Value }\end{array}$ \\
\hline Intervensi & $\begin{array}{l}23.75 \\
3.49\end{array}$ & \pm & $\begin{array}{l}25.25 \\
3.09\end{array}$ & \pm & $0.000 *$ \\
\hline Kontrol & $\begin{array}{l}23.30 \\
3.82 \\
\end{array}$ & \pm & $\begin{array}{l}24.80 \\
3.20 \\
\end{array}$ & \pm & $0.001 *$ \\
\hline & $0.700 * *$ & & $0.654 * *$ & & \\
\hline
\end{tabular}

Sumber, Data Primer 2021

*Paired T-Test

** Independen T-Test

Berdasarkan uji independent t-test ditemukan hasil bahwa motivasi berhenti merokok remaja pada kelompok intervensi dan kelompok kontrol tidak ada perbedaan yang signifikan sebelum dan sesudah perlakuan dengan nilai $p$-value $=0.700$ dan 0.654 $(\mathrm{p}>0.05)$.

\section{PEMBAHASAN}

Berdasarkan pengujian didapatkan kesimpulan analisis yakni ada perbedaan pengetahuan, frekuensi merokok, sikap dan motivasi berhenti merokok setelah mendapatkan intervensi dengan meningkatnya nilai rata-rata pengetahuan, sikap dan motivasi berhenti merokok.

Penelitian yang dilakukan menggunakan desain quasy-eksperimental dengan pre-test dan post-test control group design pada 40 responden masing-masing 20 kelompok intervensi dan 20 kelompok kontrol yang berasal dari Desa Tomado Kecamatan Lindu. Penelitian ini dilaksanakan pada bulan awal bulan April tahun 2021.

Penelitian ini dimulai dengan memberikan kuesioner pre-test kepada responden melalui media whatsapp untuk melihat sejauh mana pengetahuan, frekuensi, sikap dan motivasi berhenti merokok responden, kemudian selanjutnya dilakukan intervensi dengan flyer melalui media whatsapp kepada 20 responden kelompok intervensi. Setelah intervensi selanjutnya kembali dilakukan pengukuran pengetahuan, frekuensi, sikap, dan motivasi kepada kelompok intervensi dan kelompok kontrol melalui post-test dengan jarak waktu 15 hari setelah dilakukan intervensi.

\section{Pengetahuan}

Pengetahuan tentang resiko kesehatan dan manfaat merokok sangat penting bagi para remaja agar terhindar dari dampak buruk yang ditimbulkan dari efek merokok. Para remaja yang merokok merasa mendapatkan manfaat dari merokok dan tidak memikirkan resiko kesehatan, sedangkan remaja yang berfikir negatif tentang rokok akan menganggap bahwa perilaku merokok merupakan perilaku yang merugikan bagi Kesehatan.

Hasil uji statistik menunjukkan bahwa terdapat peningkatan pada kelompok intervensi dengan nilai pengetahuan kategori cukup sebesar 45 sebelum intervensi meningkat menjadi 65 dengan nilai mean sebelum intervensi 6.50 dan setelah intervensi menjadi 7.05 dengan $p$-value $=0.012 \quad(\mathrm{p}<0.05)$ yang berarti bahwa ada perbedaan signifikan sebelum dan sesudah intervensi. Sementara pada kelompok kontrol, hasil uji statistik menunjukkan bahwa tingkat pengetahuan responden tidak terjadi peningkatan dengan hasil sebesar 65 menjadi 60 dengan nilai $p$ value $=0.577 \quad(\mathrm{p}>0.05)$ yang berarti bahwa tidak ada perbedaan signifikan tingkat pengetahuan pada kelompok kontrol.

Berdasarkan hasil uji statistik kita dapat melihat bahwa responden yang mendapatkan intervensi mengalami peningkatan pengetahuan tentang bahaya merokok, dengan adanya peningkatan pengetahuan biasanya akan dibarengi peningkatan kesadaran untuk menjaga Kesehatan dengan berhenti merokok. Sedangkan pada kelompok kontrol berdasarkan hasil uji statistik didapatkan hasil bahwa tidak ada perubahan atau peningkatan pengetahuan 
responden, oleh karena itu diharapkan kepada guru untuk bekerjasama dalam meningkatkan pengetahuan remaja tentang bahaya merokok pada remaja dengan melakukan penyuluhan di sekolah maupun di masyarakat.

Penelitian ini didukung oleh penelitian yang dilakukan oleh Amira et al., (2019) bahwa pengetahuan siswa tentang bahaya merokok meningkat setelah diberikan intervensi dengan nilai 12 menjadi 87. Oleh karena itu penyuluhan dan intervensi mengenai bahaya merokok sangat diperlukan dilingkungan masyarakat terutama remaja.

Hasil penelitian oleh Gafar (2014) meneliti tentang pengaruh pemberian promosi kesehatan melalui media sosial Facebook terhadap pengetahuan tentang bahaya merokok pada mahasiswa PSIK Semester 8 di Universitas Muhammadiyah Yogyakarta. Metode penelitian yang dipakai adalah kuasi eksperimen dengan desain pre-post control group design. Hasil dari penelitian ini mengungkapkan bahwa tingkat pengetahuan mahasiswa sebelum dilakukan promosi kesehatan melalui media sosial Facebook berpengetahuan sedang sejumlah 20 responden (53), yang kemudian meningkat menjadi kategori tinggi sejumlah 35 responden $(92,0)$ pada akhir penelitian.

Penelitian yang dilakukan oleh (Usman, 2018) menunjukkan bahwa intervensi promosi Kesehatan melalui program konseling (perorangan, kelompok, dan massa), pemberian leaflet, pemasangan poster pada tempat-tempat umum dan pemasangan tanda dilarang merokok terbukti efektif meningkatkan pengetahuan, sikap positif dan dapat mengurangi perilaku merokok. Selain itu, penelitian yang dilakukan oleh Putra \& Hasan (2018) juga menunjukkan pentingnya promosi kesehatan dalam mengendalikan perokok dan meningkatkan kesadaran dan pengetahuan mengnai bahaya rokok.

\section{Frekuensi Merokok}

Dari hasil uji statistik menunjukkan bahwa terdapat perubahan pada frekuensi merokok kelompok intervensi dengan niali mean 8.0 menurun menjadi 7.35 dengan nilai $p$-value $=$ 0.027 ( $\mathrm{p}<0.05)$, sedangkan pada kelompok kontrol juga ditemukan hasil bahwa ada perbedaan signifikan dengan nilai mean 4.55 menurun menjadi 4.25 dengan nilai $p$-value $=$ $0.046(\mathrm{p}<0.05)$. Hasil diatas menunjukkan bahwa ada kemauan kepada para responden untuk mengurangi jumlah rokok yang dikonsumsi setalah mendapatkan intervensi menganai bahaya merokok.

Dari penelitian yang dilakukan kebanyakan frekuensi merokok remaja termasuk kategori ringan yaitu dalam sehari menghisap 1-4 batang rokok. Frekuensi merokok remaja dipengaruhi oleh beberapa faktor diantaranya yaitu uang jajan sehari-hari, tingkat stress dan juga pergaulan. Kebanyakan remaja yang mempunyai uang jajan banyak bisa menggunakannya untuk membeli rokok sehingga semakin hari frekeunsi merokoknya akan semakin meningkat, tingkat stress pada remaja juga dapat mempengaruhi frekuensi merokok karena banyak remaja yang melampiarkan atau beranggapan bahwasanya merokok akan meringankan beban fikiran mereka.

Penelitian ini sejalan dengan penelitian yang dilakukan oleh Listriawulan et al., (2017) bahwa ada perbedaan tingkat persepsi sebelum mendapatkan penyuluhan dan setelah mendapatkan penyuluhan tentang merokok kepada siswa dengan nilai $p$ value sebesar 0,000 $(\mathrm{p}<0.05)$ sehingga diharapkan dapat meningkatkan serta memaksimalkan program PIKR, pemasangan poster agar siswa lebih memahami permasalahan terkait dengan bahaya merokok.

Penelitian yang dilakukan oleh Febri (2016) menujukkan bahwa ada perbedaan siginifikan $(\mathrm{p}=0.031)$ terhadap frekuensi merokok siswa sebelum dan sesudah dilakukan intervensi dengan melalui konseling individu dengan strategi self-management. Maka dari itu diharapkan kepada pihak sekolah dan konselor untuk menggunakan strategi self-management dalam membantu siswa yang memiliki masalah khususnya tentang perilaku merokok.

Penelitian yang dilakukan oleh Golechha (2016) menunjukkan bahwa intervensi dengan menggunakan media massa dan pendekatan inovatif kemasyarakat dapat meningkatkan kesadaran individu untuk menciptakan perubahan perilaku. Selain itu, upaya yang telah dilakukan oleh masyarakat harus didasari dengan kesadaran diri sendiri dan mampu berfikir kedepan untuk Kesehatan dan kesejahteraan keluarga (Wrihatnolo \& Dwidjowijoto, 2007). 


\section{Sikap Merokok}

Sikap merupakan pendapat maupun pandangan seseorang tentang suatu objek yang mendahului tindakannya. Sikap tidak mungkin terbentuk sebelum mendapatkan informasi, melihat atau mengalami sendiri suatu objek. Sikap dibedakan menjadi dua yaitu sikap positif yang berarti sikap yang menunjukkan menerima terhadap norma yang berlaku dimana individu itu berada, maka dari itu jika sikap suatu individu itu baik otomatis pengetahuannya pastilah baik. Sedangkan yang kedua adalah sikap negatif yaitu sikap yang menunjukkan penolakan atu tidak menyetujui terhadap norma yang berlaku dimana individu itu berada.

Hasil uji statistik menunjukkan bahwa ada perbedaan signifikan antara sikap sebelum dan sesudah intervensi dimana nilai mean sebelum intervensi 38.40 dan setelah intervensi menjadi 39.60 dengan nilai $p$-value $=0.002(\mathrm{p}<0.05)$. Sedangkan pada kelompok kontrol berdasarkan hasil uji paired t-test ditemukan bahwa ada perbedaan siginifikan sikap merokok remaja dengan nilai rata-rata 33.85 menjadi 34.70 dengan nilai $p$-value $=0.003(\mathrm{p}<0.05)$.

Penelitian yang dilakukan oleh Sandhi (2019) menunjukkan bahwa sebagian besar perokok belum memahami tentang bahaya merokok bagi perokok pasif sehingga kesadaran untuk merokok di tempat-tempat umum dan jauh dari jaungkauan anak balita belum ada.

Penelitian yang dilakukan oleh Utomo et al., (2021) menunjukkan bahwa ada hubungan antara sikap dengan perilaku merokok remaja dimana biasanya dipengaruhi oleh oleh teman, faktor lingkungan dan faktor kebiasaan serta keluarga. Sehingga pencegahan dari sikap negatif remaja merokok yaitu dengan menambah pengetahuan remaja tentang bahaya merokok dengan melakukan penyuluhan, menambah wawasan keluarga tentang merokok dan disekolah guru juga harus mencegah serta menanggulangi remaja merokok agar tidak berpengaruh keteman yang lainnya.

Penelitian yang dilakukan oleh Anggraheny \& Novitasari (2019) menunjukkan bahwa penyuluhan tentang bahaya merokok dapat meningkatkan pengetahuan masyarakat tentang bahaya merokok baik perokok aktif maupun perokok pasif sehingga dapat mengubah sikap merokok masyarakat.

\section{Motivasi Berhenti Merokok}

Hasil uji statistik penelitian ini menunjukkan bahwa pada kelompok intervensi ditemukan hasil bahwa ada perbedaan signifikan motivasi berhenti merokok remaja sebelum dan sesudah intervensi dimana nilai mean sebelum intervensi 23.75 meningkat menjadi 25.25 dengan nilai $p$-value $=0.000$ $(\mathrm{p}<0.05)$. Sedangkan pada kelompok kontrol berdasarkan hasil uji paired t-test juga ditemukan bahwa ada perbedaan siginifikan dengan nilai rata-rata 23.30 menjadi 24.80 dengan nilai $p$-value $=0.001(\mathrm{p}<0.05)$.

Motivasi seseorang untuk berhenti merokok ada berbagai macam salah satunya adalah karena terjadinya pandemi covid-19 dimana menurut kemenkes, 2020 perokok lebih mungkin terjangkit COVID-19 dibandingkan dengan orang yang tidak merokok.

Penelitian yang dilakukan oleh Abdurrachman et al., (2021) menunjukkan bahwa pengetahuan, sikap, dan tindakan tentang COVID-19 memiliki hubungan yang bermakna dengan minat berhenti merokok ( $\mathrm{p}$-value $<0.05$ ). Berdasarkan analisis multivariat, variabel sikap terhadap COVID-19 merupakan variabel yang paling dominan memengaruhi minat berhenti merokok $(\mathrm{OR}=17,135)$.

Penelitian yang dilakukan oleh Milcarz et al., (2018) menyatakan bahwa perokok yang menyadari empat konsekuensi Kesehatan dari merokok menunjukkan niat untuk berhenti merokok lebih sering jika dibandingkan dengan mereka yang tidak memiliki pengetahuan tentang semua efek berbahayanya yang dianalisis dari penggunaan tembakau (19,7 vs $13,1 ; \quad \mathrm{p}<0,05)$. Olehnya itu dipelukan peningkatan pengetahuan tentang bahaya rokok baik terkait perokok aktif maupun perokok pasif dalam lingkungan masyarakat.

Penelitian yang dilakukan Fitrika (2018) menunjukkan bahwa ada perebedaan signifikan intensi berhenti merokok pada kelompok intervensi dengan nilai $\mathrm{p}=0.000$. Melakukan intervensi melaui media audio visual dapat menurunkan intensi merokok pada remaja, oleh karena itu diharapkan kepada pihak sekolah untuk lebih mengembangkan lingkungan yang kondusif dalam menunjang intervensi masalah merokok khususnya di lingkungan sekolah karena peran sekolah bagi dunia perokok remaja sangatlah penting sehingga dapat membangun 
nilai-nilai dalam diri individu bahwa merokok adalah budaya yang tidak sehat dan bukanlah sesuatu yang dapat dimaklumi, sehingga dapat meningkatkan budaya tidak merokok.

Penelitian yang dilakukan oleh (Fadilah et al., 2017) menunjukkan bahwa ada beberapa hal yang perlu diperhatikan dalam masyarakat untuk meningkatkan kemauan berhenti merokok, salah satunya yang dapat dilakukan adalah pelayanan Kesehatan yang mengintegrasikan psikologis, faktor sosial, budaya dan ekstensial fisik dengan memanfaatkan pengetahuan dan kepercayaan dalam memberikan motivasi untuk perubahan perilaku merokok.

Pemberian informasi dalam pengambilan keputusan merupakan penggabungan pengetahuan lama dengan pengetahuan baru (Ardelia \& Anwarudin, 2020). Sehingga tingkat Pendidikan dan umur harus diperhatikan dalam pemberian informasi mengenai bahaya merokok ke responden. Hal ini dikarenakan semakin tinggi pendidikan dan umur seseorang maka semakin besar pula kemampuan memahami informasi Kesehatan yang baru didapatkan (Ardia Putra, 2016).

\section{KESIMPULAN}

Adanya perbedaan yang signifikan pengetahuan responden tentang bahaya rokok pada kelompok intervensi, sedangkan pada kelompok kontrol ditemukan bahwa tidak ada perbedaan yang signifikan pada pengetahuan responden. Adanya perbedaan yang signifikan frekuensi merokok remaja pada kelompok intervensi dan kelompok kontrol. Adanya perbedaan yang siginifikan sikap merokok remaja pada kelompok intervensi maupun kelompok kontrol. Adanya perbedaan yang siginifikan motivasi berhenti merokok pada kelompok intervensi maupun kelompok kontrol.

\section{UCAPAN TERIMA KASIH}

Terima kasih diucapkan kepada pembimbing, pemerintah setempat di tempat penelitian, kerabat yang telah membantu didalam penelitian ini dan berbagai pihak lainnya yang ikut andil didalam penelitian ini.

\section{DAFTAR PUSTAKA}

Abdurrachman, M. R., Fadilah, M., \& Ridwan, A. (2021). Analisis Perilaku Kesehatan Tentang Covid-19 Terhadap Minat Berhenti Merokok Pada Perokok Aktif Di Kota Palembang. Sriwijaya University.

Amira, I., Hendrawati, H., \& Senjaya, S. (2019). Penyuluhan tentang bahaya merokok pada siswa SMAN 2. Media Karya Kesehatan, 2(1).

Anggraheny, H. D., \& Novitasari, A. (2019). Upaya Mengatasi Perilaku Merokok dengan Penyuluhan Bahaya Merokok di Kelurahan Rejosari Semarang. Prosiding Seminar Nasional Unimus, 2.

Ardelia, R., \& Anwarudin, O. (2020). Akses Teknologi Informasi Melalui Media Elektronik Pada Petani KRPL. Jurnal Triton, 11(1), 24-36.

BPS. (2020). Persentase Merokok Pada Penduduk Umur $\geq 15$ Tahun Menurut Provinsi (Persen), 2018-2020. Badan Pusat Statistik.

https://www.bps.go.id/indicator/30/1435/1/ persentase-merokok-pada-penduduk-umur15-tahun-menurut-provinsi.html

Fadilah, M., Afriandi, I., \& Rinawan, F. R. (2017). Kebiasaan Merokok Dan Pemahaman Dampak Merokok Terhadap Kesehatan Pada Perokok Pemula. Jurnal Kedokteran dan Kesehatan: Publikasi Ilmiah Fakultas Kedokteran Universitas Sriwijaya, 4(3), 106-116.

Febri, B. (2016). Perilaku Remaja Pecandu Rokok Siswa SMP Di Desa Gunung Kesiangan Kecamatan Benai Kabupaten Kuantan Singingi. JOM FISIP, 3(2), 1-15.

Fitrika, L. (2018). Pengaruh Media Audio Visual Terhadap Intensi Berhenti Merokok Pada Remaja Berbasis Theory Planned Behavior. STIKes Insan Cendekia Medika Jombang.

Gafar, G. (2014). Pengaruh Pemberian Promosi Kesehatan Melalui Media Sosial Facebook Terhadap Pengetahuan Tentang Bahaya Merokok Pada Mahasiswa PSIK semester 8 di Universitas Muhammadiyah Yogyakarta. Jurnal Keperawatan Universitas Muhammadiyah Yogyakarta.

Golechha, M. (2016). Health Promotion Methods For Smoking Prevention And Cessation: A Comprehensive Review Of 
Effectiveness And The Way Forward. International journal of preventive medicine, 7 .

Kementerian Kesehatan RI. (2012). Konsumsi Rokok dan Produk Tembaku Lainnya, Dampak Kesehatan dan Ekonomi Tembakau, Pertanian Tembakau, Industri Tembakau, Kebijakan Cukai Rokok dan Manfaatnya, dan Kebijakan Pengendalian Tembakau. Kementerian Kesehatan dan Tobacco Control Support Center - Ikatan Ahli Kesehatan Masyarakat Indonesia. http://tcsc-indonesia.org/wpcontent/uploads/2012/12/Buku-FaktaTembakau.pdf

Kementrian Kesehatan RI. (2010). Laporan Nasional RISKESDAS 2010. Badan Litbangkes - Kementerian Kesehatan RI. http://labdata.litbang.kemkes.go.id/images/ download/laporan/RKD/2010/lp_rkd2010. pdf

Kusuma, M. R. (2019). TA: Perancangan Video Iklan Layanan Masyarakat Self Harassment dengan Teknik Motion Graphic Berbasis Infografis sebagai Upaya Meningkatkan Kesadaran Masyarakat. Institut Bisnis dan Informatika Stikom Surabaya.

Kusumawardani, N., Putisari, \& Hapsari, D. (2016). Rokok dan Kesehatan. Jakarta: Lembaga Penerbit Badan Litbangkes.

Listriawulan, R., Rokhanawati, D., \& Nawangsih, U. H. E. (2017). Pengaruh Penyuluhan Terhadap Persepsi Remaja Tentang Merokok Di SMA Negeri 2 Ngaglik.

Locsin, R. C. (2007). Technological Competency As Caring in Nursing: A Model For Practice. Florida Atlantic University, Christine E. Lynn College of Nursing.

Mannocci, A., Colamesta, V., Conti, V., Cattaruzza, M. S., Paone, G., Cafolla, M., Saulle, R., Bulzomì, V., Antici, D., \& Cuccurullo, P. (2014). Demographic characteristics, nicotine dependence, and motivation to quit as possible determinants of smoking behaviors and acceptability of shocking warnings in Italy. BioMed Research International, 2014.

Milcarz, M., Polanska, K., Bak-Romaniszyn, L., \& Kaleta, D. (2018). Tobacco health risk awareness among socially disadvantaged people-a crucial tool for smoking cessation. International journal of environmental research and public health, 15(10), 2244.

Nasution, I. K. (2007). Perilaku Merokok Pada Remaja. Kedokteran USU Medan.

Notoatmodjo, S. (2007). Promosi Kesehatan \& Ilmu Perilaku. Jakarta: Rineka Cipta.

Putra, Adian, \& Hasan, I. (2018). Peranan Promosi Kesehatan Dalam Pengendalian Perokok Aktif (Studi Kasus Pada Center for Tobacco Control Studies Banda Aceh). Jurnal Ilmiah Mahasiswa Fakultas Ilmu Sosial \& Ilmu Politik, 3(1).

Putra, Ardia. (2016). Hubungan Komunikasi Terapeutik Perawat Dengan Kepuasan Pasien Di Ruang Rawat Inap Rumah Sakit Umum Daerah Dr. Zainoel Abidin, 2013. Jurnal Ilmu Keperawatan, 1(1).

Ramdhani, L. F., Laili, F., Cicard, Z. M. V. M. D., \& Jumlah, S. A. U. M. (2014). Cigarette Vending Machine Dan Cicard "Solusi Alternatif Untuk Mengurangi Jumlah Perokok Aktif Dibawah Umur." Jurnal Ilmiah Mahasiswa, 4(1).

Republik Indonesia. (2013). Peraturan Menteri Kesehatan Nomor 28 Tahun 2013. Pencantuman Peringatan Kesehatan dan Informasi Kesehatan pada Kemasan Produk Tembakau. BPK RI. https://peraturan.bpk.go.id/Home/Details/1 30049/permenkes-no-28-tahun-2013

Rochayati, A. S., \& Hidayat, E. (2015). Faktorfaktor yang mempengaruhi Perilaku Merokok remaja di sekolah Menengah kejuruan kabupaten kuningan. Jurnal Keperawatan Soedirman, 10(1), 1-11.

Sandhi, S. I. (2019). Studi Fenomenologi: Kesadaran Diri (Self Awareness) Perokok Aktif yang mempunyai Anak Balita dalam Perilaku Merokok di Tempat Umum di Kelurahan Pegulon Kabupaten Kendal. Jurnal Kebidanan Harapan Ibu Pekalongan, 6, 237-243.

UNICEF Indonesia. (2021). Remaja Indonesia Berkomitmen Berhenti Merokok Pada Hari Tanpa Tembakau Sedunia. UNICEF Indonesia.

https://www.unicef.org/indonesia/id/stories /remaja-indonesia-berkomitmen-berhentimerokok-pada-hari-tanpa-tembakausedunia 
Usman, S. (2018). Pengaruh Promosi Kesehatan Terhadap Perubahan Perilaku Merokok Karyawan (Studi Kasus di Rumah Sakit Umum Daerah Dr. Zainoel Abidin Banda Aceh). Majalah Kesehatan Masyarakat Aceh (Makma), 1(1), 1-12.

Utomo, E., Fajar, N. A., \& Misnaniarti, M. (2021). Pola Asuh Orang Tua Otoriter, Demokratis, Permisif Dengan Perilaku Merokok Pada Siswa Smp Di Kota Palembang. Jurnal'Aisyiyah Medika, 6(1).

WHO. (2020). Pernyataan: Hari Tanpa Tembakau Sedunia 2020. World Health Organization.

https://www.who.int/indonesia/news/detail/ 30-05-2020-pernyataan-hari-tanpatembakau-sedunia-2020

Wrihatnolo, R. R., \& Dwidjowijoto, R. N. (2007). Manajemen Pemberdayaan: Sebuah Pengantar dan Panduan untuk Pemberdayaan Masyarakat. Jakarta: Elex Media Computindo. 